\title{
CONCEPTION OF MEDIA EDUCATION
}

\section{Wojciech WALAT}

\begin{abstract}
The diagnosis of the problem of the contemporary world in the area of global media communication is a basic challenge for existing and modernised educational systems. Without a complete vision of the world, people cannot exist in a fully aware way. Hence, the most important questions related to such social development in which no one would be excluded from the world-wide circulation of information. The general assumptions of common media education have been presented in the article.
\end{abstract}

Key words: media education, technology information.

\section{KONCEPCJA EDUKACJI MEDIALNEJ}

Streszczenie: Diagnoza problemów wspótczesnego świata $w$ zakresie globalnej komunikacji medialnej jest podstawowym wyzwaniem dla istniejacych i modernizowanych systemów edukacyjnych. Bez petnej wizji świata czlowiek nie może istnieć w pelni świadomie. Stąd najważniejsze pytania związane sa z takim rozwojem społecznym, w którym każdy człowiek nie będzie wykluczony $z$ ogólnoświatowego obiegu informacji. $W$ artykule zostały przedstawione ogólne założenia powszechnej edukacji medialnej.

Słowa kluczowe: edukacja medialna, technologie informacyjne.

\section{Introduction}

Educational needs have been forcefully altered by the developing information society, making the following necessary:

1) increasing independence and individualism in the area of work and production organisation,

2) internationalisation of trade,

3) development of the world of science and technology [1].

As a consequence of these changes, education concentrates on general culture. Man will be forced to understand complex unpredictable situations and to interpret large quantities of news, often non-systematised, in a flood of information broadcast by the mass media and hypermedia. The task of schooling is to teach one to perceive the sense of the world, to understand its functioning and to aid in finding one's own lifestyle based on an awareness of the citizenship of one's own country and Europe. The main task of education is to help individuals in shaping their character, cultural openness and social sensitivity [2].

\section{Media education in the system of general education}

Recognition of the global problems of the contemporary world is the most significant educational challenge. People cannot exist in a fully aware way without an "orientating vision of the world". Therefore, the most significant issues from the life of our planet are transferred on a regular basis by particular mass media in countries all over the world. They are largely discussed, shown, but not efficiently enough to make them fully comprehensible.

The basic aim of media education is to educate in the area of media so that students can understand their nature and influence and use them reasonably in didactic and educational situations [3]. Media education is a practical exemplification of a new pedagogical subdiscipline - media pedagogy. Media education has become an indispensable area of general education because the media has become a reality in everybody's life. The lack of media education can pose a threat in the form of serious social consequences both as far as the selection of the media used is concerned as well as in its use.

Within the framework of the educational system reform, the Ministry of National Education introduced a new "educational path" to schools in 2002 called Media and reading education [4], and within the 'minimum' curriculum a subject called Media in education has been taught during studies in the faculty of "pedagogy" since 2000.

The introduction of the subject path Media and reading education was brought about by three main rationales [5]: 
1) A dynamic development of the mass media and hypermedia, and their dominant significance in cultural changes taking place. The media decides on the shape and character of popular culture, intensifies globalisation processes, and also favours a process to the contrary - customisation of the "production" of programmes and their reception. They [in the media] popularise culture to an incredible extent, meet and create needs, interests, likes, and they influence the stimulation and re-evaluation of creative attitudes.

2) The media plays a dominant role in education - institutional, social and constant, education without age, social and cultural, or national limits. It is the only "window to the world" and omnipotent source of information for numerous illiterates. The media orientates onto the global problems of the world, broadens horizons and compensates for a lack of contact with schooling. In the case of highly educated people, the media can be negatively perceived, but it can also have positive functions including the generation of new information as well as influencing the way of thinking.

3) The incredible development of the media, its hard-to-grasp rich programme, diversified both in content and form, drives new educational steps to teach the effective use of the media, beginning with the stage of the ability to choose programs selectively to enriching their reception. Contrary to popular belief, this task is not easy. Apart from discrimination in the wide-range offer, it aims at taking into account the psycho-social and cultural predispositions of recipients learning the peculiar language of the media, and in the case of multimedia the mastering of the principles of using the information and communication technologies or people's capabilities of communicating with computers and interpreting a large set of incoherent and partial information. The expected result of such selective choice and reception is to obtain and assimilate information, develop interests, and shape desired social attitudes. The use of such didactic measures, which, by integrating various media, would introduce "cognitive order" in the information noise surrounding people, could prepare them for creative existence in the contemporary and everchanging reality.

So far, the media education of teachers, pupils, and students has concerned mainly the ability to use didactic means and the mass media in aid of the educational process, improvements aimed at the increase in efficiency of didactic work. However, threats were omitted, such as the content and forms of media news, which could cause noticeable social dangers by shaping negative attitudes in the recipients' consciousness [6] [7]. The media can significantly influence the form, content, and speed of the indirect communication process and reduce direct communication.

Media education is to prepare the recipient not only for learning the latest educational technologies, for the reception of the contents transferred by the media selectively, actively, and thoroughly; it also takes into account learning practical principles of their use by the recipient as tools aiding the individuals' intellectual actions, their development, and co-creating and creating educational curricula and their popularisation by the media on a micro and macro scale. In general, media education has three basic tasks to fulfil [8]: - preparation for the correct (critical) reception of the media as tools of transferring information and shaping a system of values and attitudes;

- preparation for using the media as tools for intellectual development (self-development) and professional work (giving selected actions to the media);

- preparation for rational use of media as instruments of play and entertainment.

The main curricular assumptions of media education in the era of globalisation and the information society include three directions of activity:

1) media education includes the printed word, graphics and sound, as well as motion and motionless pictures provided by each type of technology [9], [10];

2) in general, media education prepares people to understand the communication media operating in their countries and the ways they operate; it also teaches them to use the media for mutual communication;

3) in particular, media education prepares people to:

- analyse, critically assess and create media texts,

- identify sources of media texts and their political, social and cultural context,

- interpret news and values offered by the media,

- match suitable media to their own news and relations aimed at specific recipients,

4) providing society with access to the media both as far as their reception and creation is concerned. 


\section{Common media education}

The place for implementing media education is not only school, it also covers the whole of society. The basic aim of media education in schools and throughout continuous education is to develop key information competences that allow people to live creatively and with dignity in the constantly developing information society [11].

The reception of mass media amounts to teaching the latest educational technologies, to selective and active reception of contents transferred by these media and to co-creating and creating educational curricula.

The sudden increase and even deluge of information, doubling of scientific knowledge in a relatively short period of time and frequent changes of work and the necessity to retrain, and the necessity of training oneself systematically as part of the whole working population has set education with the main task of becoming familiar with ways of rapid and effective learning, including the ability to use available information. This is a wide range of diversified tasks set for all levels and types of education.

The classical and basic educational tasks include developing fast reading and fast notetaking techniques, the ability to search for necessary information and to use its various sources, and especially the latest educational technology following from the development of microelectronics. What this mainly concerns is computerisation - getting to know the principles of operation and possibilities of application of computers, the ability to code information, and search for it and process it. The intensive development of science and technology is impossible without complex computer software, memory banks and information processing. Using computers in art also gives a new artistic value. Computer music and graphics are common. Thanks to computers, it is possible to model almost anything - from the phenomena of cognitive character to the artistic. In the case of the mass media, it is necessary to teach the selective - i.e. conscious - choice of the most valuable items and their thorough reception [2] exercising the ability to receive media selectively and critically [12].

It is an exceptionally vital problem in the contemporary world, where various offers of relatively low level of values (moral, substantial, and aesthetic) are given to people. An important pedagogical task follows from the above: to teach to choose, to introduce into the mysteries of the language of transmission and to aesthetically sensitise so that the recipient does not feel helpless when faced with a spate of various contents. Therefore, it is all about procedures to facilitate reception that is to be complete and comprehensive, characterised by perception of all layers, and the emotional and intellectual involvement. Such a selective choice of recognised and active (thorough) reception is valuable. From the pedagogical point of view, it is used for developing cultural interests, awakening aesthetic taste, developing socially desired attitudes, and, in a way, it prepares for creative participation in life.

The principle of treating recipients as subjects can, for example, be achieved by co-creating the hypermedia curricula. It is both about increased thematic diversification and increased relevant international directing the offer to a bigger number of various spheres of interest and obtaining feedback between the recipient and the broadcaster as it takes place in 'contact radio shows" (broadcast "live").

The reception of the media in this way suggests the correctness of the theory of use and benefit, aimed at educated and active people. It accurately shows receptive behaviour as being aware, purposeful and selective, i.e. fully controlled by individuals. However, the richness, variety, and ambiguity of mass transmissions, together with sophisticated manipulation technologies, question the problem of people's control over the mass media and multimedia - which is the right selection and how to make a sensible use in receiving them? The process of developing the ability to use the media in an enriching way is the basic task of education, regardless of the achieved result.

The dynamically developing information society requires educational processes to undergo constant adaptive and creative changes. If we assume that education is a process of the aware use of information for developing one's psyche, the gradual (including the period of school education, education outside school and education in life in general) development of key information competences is assumed to be the basis of this process.

\section{Assumptions of common media education}

The assumptions used for developing the Hypermedia Didactic Curricula (HPD) following from the specification of their role in the processes of education understood in this way can be divided into four basic groups: 
A) The developing information society requires changes to the educational system in terms of the model of preparing people who are capable of acquiring knowledge to a model of people prepared for creating knowledge. Solutions used in hypermedia didactic curricula can enable, in the educational processes, the gradual transfer from adaptive philosophy to critical and creative philosophy expressed in preparing students for solving problems in a creative way by mastering heuristic methods, such as:

- recognition of the initial situation and formulating the aim of actions,

- analysing information in the initial situation,

- designing the final situation,

- planning actions,

- preparing necessary measures,

- performing,

- evaluating results and drawing conclusions optimising actions [13].

B) The analysis of terms such as media, multimedia or information technologies shows the integration and interactive character of hypermedia transmission, whose basis are the information technologies, based on theoretical and practical achievements of communication processes expressed in preparing students for:

- communication with the use of the latest and various generation media (integrated by information technologies);

- deciphering, correct interpretation, creation and preparation of various types of messages;

- co-creation, creation and presentation of various audio, audio-visual and hypermedia forms.

C) Due to free and practically unlimited access to information resources, special attention is paid to processes of cognition and internalisation of values. Therefore, hypermedia didactic curriculum can:

- teach selective and critical reception of media (develop the ability to rationalise choices made);

- support artistic and technical work;

- involve the emotion and intellect;

- support developing socially desired attitudes.

D) The development of key competences determined by constantly updated educational standards, including the following, can be supported by the multimedia and hypermedia transmission used:

- information abilities which have a practical and intellectual character and are related to the efficiency of using IT equipment;

- information abilities which have an intellectual and practical character and are related to intellectual methods of processing information by people, which are abilities related to searching for (obtaining, receiving) information from the environment, processing it (incorporating into the individual system of knowledge) and introducing it in the form of work (ideas, projects) and outputs of the environment.

\section{Literature}

[1] Poland in the road to global information society. Social development report. Warsaw 2002.

[2] Gajda J., Media in education. Wyd. II, Oficyna Wyd. Impuls, Kraków 2003.

[3] Walat W., Educational uses of hypermedia. Wyd. UR, Rzeszów 2007.

[4] The decree of Minister of National Education with day 26 February 2002: in matter of program basis of preschool education as well as the general education in individual types of schools.

[5] Gajda J., Juszczyk S., Siemieniecki B., Wenta K., Media education, Wyd. A. Marszałek, Torun 2003.

[6] Chráska M., Chrásková M., Postoje žáků různých typu střednich škol k osobnimu počitači [w:] Technika informatyka - edukacja. Teoretyczne $i$ praktyczne problemy edukacji informatycznej. Suplement. Rzeszow 2007, s. 17 - 27, ISBN 978-83-88845-94-9.

[7] Juszczyk S., The man in world of electronic medias the chances and threat, Katowice 2000.

[8] Strykowski W., Pedagogy and education mediumistic in informative society [w:] Media education in informative society. Red. S. Juszczyk, Wyd.

A. Marszałek, Torun 2002, s. 19.

[9] Dostál J., Interaktivni tabule ve vzdělávání [In:] Education - Technology - Computer Science. Theoretical and practical problems of informatics and information education. Vol. XII. University of Rzeszow 2009, p. 133-138. ISBN 978-83-7586-026-9.

[10] Szotkowski R., Dotyková interaktivni tabule $z$ hlediska žáků základních škol [In:] Education Technology - Computer Science. Theoretical and practical problems of informatics and information education. Vol. XII. University of Rzeszow 2009, p. 139144. ISBN 978-83-7586-026-9.

[11] Havelka M., Serafín Č., Conception of teaching effectiveness supported by information technologies [In:] Education - Technology - Computer Science. Theoretical and practical problems of informatics and information education. Vol. XII. University of Rzeszow 2009, p. 77-81. ISBN 978-83-7586-026-9.

[12] Klement M., Lavrinčík J., Projekt „IVOŠ - zvýšení kvality ve vzdělávání zavedením interaktivní výuky do škol” [In:] Trendy ve vzdělávání 2009. Olomouc 2009, p. 10-14. ISBN ISBN 978-80-7220-316-1.

[13] Lib W., Methodology of the elaboration multimedia didactic programmes. "Technology and Society", Zadar 2006.

Doc. PhD. Wojciech Walat

Institute of Technology, University of Rzeszow

Rejtana Street 16A, 35-310 Rzeszów, Poland

E-mail: walat@univ.rzeszow.pl 